\title{
Correction to: Properties of a superelastic NiTi shape memory alloy using laser powder bed fusion and adaptive scanning strategies
}

\author{
Tobias Gustmann $^{1}$ D $\cdot$ Florian Gutmann ${ }^{2} \cdot$ Franziska Wenz $^{3} \cdot$ Peter Koch $^{4} \cdot$ Ralph Stelzer $^{4} \cdot$ Welf-Guntram Drossel $^{1}$. \\ Hannes Korn ${ }^{1}$
}

Published online: 9 August 2021

(c) The Author(s) 2021

\section{Correction to: \\ Progress in Additive Manufacturing (2020) 5:11-18 \\ https://doi.org/10.1007/s40964-020-00118-6}

The article Properties of a superelastic NiTi shape memory alloy using laser powder bed fusion and adaptive scanning strategies, written by Tobias Gustmann, Florian Gutmann, Franziska Wenz, Peter Koch, Ralph Stelzer, Welf-Guntram Drossel and Hannes Korn, was originally published Online First without Open Access. After publication in volume 5 , issue 1, page 11-18 the author decided to opt for Open Choice and to make the article an Open Access publication. Therefore, the copyright of the article has been changed to The Author(s) 2020 and the article is forthwith distributed under the terms of the Creative Commons Attribution Attribution 4. 0 International License, which permits use, sharing, adaptation, distribution and reproduction in any medium or format, as long as you give appropriate credit to the original author(s) and the source, provide a link to the Creative Commons licence, and indicate if changes were made. The images or other third party material in this article are included in the article's Creative Commons licence, unless indicated otherwise in a credit line to the material. If material is not included in the article's Creative Commons licence and your intended use is not permitted by statutory regulation or exceeds the permitted use, you will need to obtain permission directly from the copyright holder. To view a copy of this licence, visit http://creativecommons. org/licenses/by/4.0.

Open Access This article is licensed under a Creative Commons Attribution 4.0 International License, which permits use, sharing, adaptation, distribution and reproduction in any medium or format, as long as you give appropriate credit to the original author(s) and the source, provide a link to the Creative Commons licence, and indicate if changes were made. The images or other third party material in this article are included in the article's Creative Commons licence, unless indicated otherwise in a credit line to the material. If material is not included in the article's Creative Commons licence and your intended use is not permitted by statutory regulation or exceeds the permitted use, you will need to obtain permission directly from the copyright holder. To view a copy of this licence, visit http://creativecommons.org/licenses/by/4.0/.

Publisher's Note Springer Nature remains neutral with regard to jurisdictional claims in published maps and institutional afliations.

The original article can be found online at https://doi.org/10.1007/ s40964-020-00118-6.

Tobias Gustmann

tobias.gustmann@iwu.fraunhofer.de

1 Fraunhofer Institute for Machine Tools and Forming, Technology IWU, Dresden, Germany

2 Fraunhofer Institute for High-Speed Dynamics (Ernst-Mach-Institut) EMI, Freiburg, Germany

3 Fraunhofer Institute for Mechanics of Materials IWM, Freiburg, Germany

4 Chair of Engineering Design and CAD, Technical University Dresden, Dresden, Germany 